ISSN 0258-7122

Bangladesh J. Agril. Res. 34(2) : 181-187, June 2009

\title{
EFFECT OF BLACK POINT DISEASE ON QUALITY OF WHEAT GRAIN
}

\author{
P. K. MALAKER ${ }^{1}$, I. H. MIAN ${ }^{2}$, K. A. BHUIYAN ${ }^{3}$ \\ M. M. A. REZA ${ }^{4}$ AND M. A. MANNAN ${ }^{5}$
}

\begin{abstract}
An experiment was conducted to determine the effect of different levels of black point infection caused by Bipolaris sorokiniana and other fungal pathogens on some quality characters of wheat grain. Wheat grains were graded on a 0-5 scale based on levels of black point infection. Quality characters of grain viz., protein, fat, dry matter, ash and mineral contents under different grades were determined following standard methods. The dry matter and ash contents of grain decreased while the contents of protein and fat increased with the increasing severity of black point infection. The observations on macro and micro nutrient contents of grain indicated that the amount of nitrogen, phosphorus, calcium, magnesium, sulphur, and boron increased, whereas the contents of potassium, iron, zinc, copper and sodium decreased with the increase of black point infection. However, the reductions in copper content of black point affected grains under different grades of infection were not significant as compared to apparently healthy grains.
\end{abstract}

Key Words: Black point, Bipolaris sorokiniana, grain quality, wheat.

\section{Introduction}

Wheat is attacked by about 20 different diseases at various stages of its growth in Bangladesh (Ahmed, 1994). Among them, five are considered to be economically important because of their damaging nature and wide occurrence throughout the wheat growing areas of the country. Black point caused mainly by Bipolaris sorokiniana, Alternaria alternata, Cladosporium cladosporioides, Curvularia lunata and Fusarium spp. is one of them (Fakir, 1998). The disease is characterized by brown to black discolouration usually restricted to the embryonic end of the grain, but in case of severe infection, the whole grain may be discoloured and shrivelled (Hanson and Christensen, 1953; Adlakha and Joshi, 1974). The disease occurs almost all over the world wherever wheat is grown (Mathur and Cunfer, 1993). In Bangladesh, the prevalence of the disease was found to vary from 5 to $55 \%$ depending on different varieties grown in the major wheat growing areas (Dey et al., 1992). Black point infection becomes severe when prolonged wet weather prevails during grain filling period of the crop.

${ }^{1}$ Principal Scientific Officer, Wheat Research Centre, BARI, Dinjpur-5200, ${ }^{2 \& 3}$ Professor, BSMRAU, Gazipur-1706, ${ }^{4}$ Senior Scientific Officer, Wheat Research Centre, BARI, Dinajpur-5200, ${ }^{5}$ Senior Scientific Officer, Farm Division, BARI, Gazipur-1701, Bangladesh. 
Black point has an adverse effect on seed weight, germination, and seedling emergence (Khanum et al., 1987; Rahman and Islam, 1998). However, the reduction in grain weight and germination was found to be related with the severity of black point infection. Increased seedling mortality and reduced seedling vigour and grain yield are also experienced when black pointed seeds are used for sowing (Rashid, 1998; Hossain, 2000; Malaker and Mian, 2002). Because of black discolouration and lower germination of the black point affected seeds, the seed producing agencies like Bangladesh Agricultural Development Corporation, Directorate of Agricultural Extension, Seed Companies and some Non- Government Organizations have often been rejecting considerable quantity of wheat seeds inflicting appreciable economic loss.

Black point also affects lustre and plumpness of wheat grain and reduces its market value (Rees et al., 1984; Chaudhary et al., 1984; Solanki et al., 2006). When wheat grain with black point is milled, undesirable black specks may occur in the semolina and macaroni produced from it (Prescott et al., 1986). Severe black point infection of grains has also been found to result in reduced cooked weight of macaroni and to affect its tenderness. Minor changes in dough character and taste, and increase in undesirable colour of flour derived from grains with high levels of black point have also been reported (King et al., 1981). Since most of the consumers of Bangladesh buy wheat grain from the market and later get it milled for making 'Chapati', the physical characteristics, such as grain colour, texture, lustre, size, mottling, uniformity of size, etc. are given important considerations. But nutritional qualities in relation to black point infection of grains have been paid less attention. The present work was, therefore, undertaken to determine the effect of different levels of black point infection on some important quality characters of wheat grain.

\section{Materials and Method}

The experiment was conducted at Bangabandhu Sheikh Mujibur Rahman Agricultural University (BSMRAU), Gazipur during 1999-2000 crop season. Seeds of a popular wheat variety 'Kanchan' were obtained from the Wheat Testing Station, Bangladesh Agricultural Research Institute (BARI), Gazipur. The seeds were separated into six different grades on the basis of severity of black point infection. The grading was done according to $0-5$ rating scale as suggested by Gilchrist (1985), where,

Grade- 0 = Grains free from any discolouration (apparently healthy);

Grade-1 = Tip of the embryo brown to blackish;

Grade-2 = Discolouration covering the whole embryo;

Grade-3 = Embryo with 1/4 of the grain discoloured;

Grade-4 = Embryo with 1/2 of the grain discoloured;

Grade-5 = Embryo with more than 1/2 of the grain discoloured and shrivelled. 
Quality characters viz., protein, fat, dry matter, ash, and mineral contents of wheat grains under different grades were determined. Dry matter and ash contents were measured following the procedures of Banerjee (1978). Protein and fat contents were determined following the methods of AOAC (Helrich, 1990). The mineral constituents of grains under different grades were assessed following the methods suggested by Hunter (1984). Data on different quality characters were analyzed statistically using MSTAT-C computer programme and means were compared by DMRT.

\section{Results and Discussion}

Black point infection of grains showed marked influence on protein, fat, dry matter, and ash content of wheat grains. Significant variations in these characters were found among different grades of black point affected grains. The protein content was the lowest in apparently healthy grains (Grade-O), which was statistically similar to that recorded under the black point affected grains of Grade-1. The maximum protein content was found in grains under Grade-5, which was followed by Grade-4, Grade-3, and Grade-2. The parameter under Grade-1 to Grade-5 was significantly different. The fat content was minimal in grains under Grade-O, which was statistically similar to those of Grade-I and Grade-2. The fat contents of black point affected grains under Grade- 4 and Grade-5 were statistically similar, but significantly higher as compared to grains under the other four categories. The dry matter and ash contents of apparently healthy grains (Grade-O) and black point affected grains under Grade-I were statistically similar, but significantly higher when compared to those of the other grades of black point affected grains. The lowest dry matter and ash contents were observed under Grade-5, which was followed by Grade-4, Grade-3, and Grade-2. The parameters under the four higher grades of black point infection were significantly different (Table 1 ).

Table 1. Effect of different grades of black point infection on protein, fat, dry matter, and ash contents of wheat grain.

\begin{tabular}{l|l|l|l|l}
\hline $\begin{array}{c}\text { Grades of black } \\
\text { point }\end{array}$ & $\begin{array}{c}\text { Protein content } \\
\text { (\%) }\end{array}$ & Fat content (\%) & $\begin{array}{c}\text { Dry matter } \\
\text { content (\%) }\end{array}$ & Ash content (\%) \\
\hline Grade-0 & $12.51 \mathrm{e}$ & $1.75 \mathrm{c}$ & $89.79 \mathrm{a}$ & $2.33 \mathrm{a}$ \\
Grade-1 & $12.64 \mathrm{e}$ & $1.76 \mathrm{c}$ & $89.57 \mathrm{a}$ & $2.27 \mathrm{a}$ \\
Grade-2 & $13.25 \mathrm{~d}$ & $1.80 \mathrm{c}$ & $88.99 \mathrm{~b}$ & $2.1 \mathrm{Db}$ \\
Grade-3 & $14.22 \mathrm{c}$ & $1.87 \mathrm{~b}$ & $88.26 \mathrm{c}$ & $2.00 \mathrm{c}$ \\
Grade-4 & $15.67 \mathrm{~b}$ & $1.98 \mathrm{a}$ & $87.74 \mathrm{~d}$ & $1.63 \mathrm{~d}$ \\
Grade-5 & $16.77 \mathrm{a}$ & $2.00 \mathrm{a}$ & $87.28 \mathrm{e}$ & $1.47 \mathrm{e}$ \\
\hline CV $(\%)$ & 2.06 & 1.84 & 0.17 & 2.48 \\
\hline
\end{tabular}

Means within a column followed by a common letter do not differ significantly $(p=0.05)$. 
Table 2. Effect of different grades of black point infection on the content of macro and micro nutrient elements in wheat grain.

\begin{tabular}{|c|c|c|c|c|c|c|c|c|c|c|c|}
\hline \multirow{2}{*}{$\begin{array}{c}\text { Grades of } \\
\text { black point }\end{array}$} & \multicolumn{11}{|c|}{ Nutrient elements (\% dry weight) } \\
\hline & $\mathrm{N}$ & $\mathrm{P}$ & $\mathrm{K}$ & $\mathrm{Ca}$ & $\mathrm{Mg}$ & $\mathrm{S}$ & $\mathrm{Fe}(\mathrm{ppm})$ & Zn (ppm) & $\mathrm{Cu}(\mathrm{ppm})$ & $\mathrm{B}(\mathrm{ppm})$ & $\mathrm{Na}$ \\
\hline Grade-0 & $2.19 \mathrm{e}$ & $0.45 \mathrm{e}$ & $0.50 \mathrm{a}$ & $0.06 \mathrm{~d}$ & $0.11 \mathrm{c}$ & $0.07 \mathrm{c}$ & $94.45 \mathrm{a}$ & $36.75 \mathrm{a}$ & 19.37 a & $25.55 \mathrm{f}$ & $1.25 \mathrm{a}$ \\
\hline Grade-1 & $2.22 \mathrm{e}$ & $0.46 \mathrm{e}$ & $0.49 \mathrm{a}$ & $0.07 \mathrm{~d}$ & $0.12 \mathrm{c}$ & $0.07 \mathrm{c}$ & $93.42 \mathrm{ab}$ & $33.00 \mathrm{~b}$ & $18.75 \mathrm{a}$ & 29.55 e & $1.15 \mathrm{~b}$ \\
\hline Grade-2 & $2.32 \mathrm{~d}$ & $0.49 \mathrm{~d}$ & $0.46 \mathrm{~b}$ & $0.10 \mathrm{c}$ & $0.15 \mathrm{~b}$ & $0.09 \mathrm{~b}$ & $93.42 \mathrm{ab}$ & $28.25 \mathrm{c}$ & 18.75 a & $35.33 \mathrm{~d}$ & 0.92 c \\
\hline Grade-3 & $2.49 c$ & $0.51 \mathrm{c}$ & $0.44 \mathrm{c}$ & $0.13 b$ & $0.15 b$ & $0.10 \mathrm{~b}$ & 93.42ab & $27.00 \mathrm{c}$ & $18.25 \mathrm{a}$ & $38.00 \mathrm{c}$ & $0.82 \mathrm{~d}$ \\
\hline Grade-4 & $2.75 \mathrm{~b}$ & $0.54 \mathrm{~b}$ & $0.41 \mathrm{~d}$ & $0.14 \mathrm{~b}$ & $0.17 \mathrm{a}$ & $0.12 \mathrm{a}$ & $91.30 \mathrm{bc}$ & $24.50 \mathrm{~d}$ & $17.50 \mathrm{a}$ & $46.96 \mathrm{~b}$ & 0.69 e \\
\hline Grade-5 & $2.94 \mathrm{a}$ & $0.56 \mathrm{a}$ & $0.40 \mathrm{~d}$ & $0.16 \mathrm{a}$ & $0.18 \mathrm{a}$ & $0.12 \mathrm{a}$ & 90.27 c & $24 \mathrm{M} 0 \mathrm{~d}$ & $17.50 \mathrm{a}$ & $53.22 \mathrm{a}$ & $0.65 \mathrm{e}$ \\
\hline $\mathrm{CV}(\%)$ & 2.06 & 2.76 & 3.44 & 7.13 & 4.93 & 6.84 & 2.01 & 4.64 & 10.57 & 4.04 & 4.06 \\
\hline
\end{tabular}

Means within a column followed by a common letter do not differ significantly $(p=0.05)$. 
Table 2. Effect of different grades of black point infection on the content of macro and micro nutrient elements in wheat grain.

\begin{tabular}{|c|c|c|c|c|c|c|c|c|c|c|c|}
\hline \multirow{2}{*}{$\begin{array}{c}\text { Grades of } \\
\text { black point }\end{array}$} & \multicolumn{11}{|c|}{ Nutrient elements (\% dry weight) } \\
\hline & $\mathrm{N}$ & $\mathrm{P}$ & $\mathrm{K}$ & $\mathrm{Ca}$ & $\mathrm{Mg}$ & $\mathrm{S}$ & $\mathrm{Fe}(\mathrm{ppm})$ & Zn (ppm) & $\mathrm{Cu}(\mathrm{ppm})$ & $\mathrm{B}(\mathrm{ppm})$ & $\mathrm{Na}$ \\
\hline Grade-0 & $2.19 \mathrm{e}$ & $0.45 \mathrm{e}$ & $0.50 \mathrm{a}$ & $0.06 \mathrm{~d}$ & $0.11 \mathrm{c}$ & $0.07 \mathrm{c}$ & $94.45 \mathrm{a}$ & $36.75 \mathrm{a}$ & 19.37 a & $25.55 \mathrm{f}$ & $1.25 \mathrm{a}$ \\
\hline Grade-1 & $2.22 \mathrm{e}$ & $0.46 \mathrm{e}$ & $0.49 \mathrm{a}$ & $0.07 \mathrm{~d}$ & $0.12 \mathrm{c}$ & $0.07 \mathrm{c}$ & $93.42 \mathrm{ab}$ & $33.00 \mathrm{~b}$ & $18.75 \mathrm{a}$ & 29.55 e & $1.15 \mathrm{~b}$ \\
\hline Grade-2 & $2.32 \mathrm{~d}$ & $0.49 \mathrm{~d}$ & $0.46 \mathrm{~b}$ & $0.10 \mathrm{c}$ & $0.15 \mathrm{~b}$ & $0.09 \mathrm{~b}$ & $93.42 \mathrm{ab}$ & $28.25 \mathrm{c}$ & 18.75 a & $35.33 \mathrm{~d}$ & 0.92 c \\
\hline Grade-3 & $2.49 c$ & $0.51 \mathrm{c}$ & $0.44 \mathrm{c}$ & $0.13 b$ & $0.15 b$ & $0.10 \mathrm{~b}$ & 93.42ab & $27.00 \mathrm{c}$ & $18.25 \mathrm{a}$ & $38.00 \mathrm{c}$ & $0.82 \mathrm{~d}$ \\
\hline Grade-4 & $2.75 \mathrm{~b}$ & $0.54 \mathrm{~b}$ & $0.41 \mathrm{~d}$ & $0.14 \mathrm{~b}$ & $0.17 \mathrm{a}$ & $0.12 \mathrm{a}$ & $91.30 \mathrm{bc}$ & $24.50 \mathrm{~d}$ & $17.50 \mathrm{a}$ & $46.96 \mathrm{~b}$ & 0.69 e \\
\hline Grade-5 & $2.94 \mathrm{a}$ & $0.56 \mathrm{a}$ & $0.40 \mathrm{~d}$ & $0.16 \mathrm{a}$ & $0.18 \mathrm{a}$ & $0.12 \mathrm{a}$ & 90.27 c & $24 \mathrm{M} 0 \mathrm{~d}$ & $17.50 \mathrm{a}$ & $53.22 \mathrm{a}$ & $0.65 \mathrm{e}$ \\
\hline $\mathrm{CV}(\%)$ & 2.06 & 2.76 & 3.44 & 7.13 & 4.93 & 6.84 & 2.01 & 4.64 & 10.57 & 4.04 & 4.06 \\
\hline
\end{tabular}

Means within a column followed by a common letter do not differ significantly $(p=0.05)$. 